\title{
The Prospects for Hybrid Electric Vehicles, 2005-2020: Results of a Delphi Study
}

\author{
Henry K. Ng, Anant D. Vyas, and Danilo J. Santini \\ Center for Transportation Research \\ Energy Systems Division \\ Argonne National Laboratory \\ 9700 South Cass Avenue \\ RECEIVE⿱ \\ Argonne, Illinois 60439-4845
}

\section{ABSTRACT}

The introduction of Toyota's hybrid electric vehicle (HEV), the Prius, in Japan has generated considerable interest in HEV technology among U.S. automotive experts. In a follow-up survey to Argonne National Laboratory's two-stage Delphi Study on electric and hybrid electric vehicles (EVs and HEVs) during 1994-1996, Argonne researchers gathered the latest opinions of automotive experts on the future "top-selling" HEV attributes and costs. The experts predicted that HEVs would have a spark-ignition gasoline engine as a power plant in 2005 and a fuel cell power plant by 2020 . The projected 2020 fuel shares were about equal for: gasoline and hydrogen, with methanol a distant third. In 2020, HEVs are predicted to have series-drive, moderate battery-alone range and cost significantly more than conventional vehicles (CVs). The HEV is projected to cost $66 \%$ more than a $\$ 20,000 \mathrm{CV}$ initially and $33 \%$ more by 2020 . Survey respondents view batteries as the component that contributes the most to the HEV cost increment. The mean projection for battery-alone range is $49 \mathrm{~km}$ in $2005,70 \mathrm{~km}$ in 2010 , and $92 \mathrm{~km}$ in 2020 . Responding to a question relating to their personal vision of the most desirable HEV and its likely characteristics when introduced in the U.S. market in the next decade, the experts predicted their "vision" HEV to have attributes very similar to those of the "topselling" HEV. However, the "vision" HEV would cost significantly less. The experts projected attributes of three leading batteries for HEVs and projected acceleration times on battery power alone. The resulting battery packs are evaluated, and their initial and replacement costs are analyzed. These and several other opinions are summarized.

\section{INTRODUCTION}

The Argonne National Laboratory conducted a two-stage Delphi Study on electric and hybrid electric vehicles (EVs and HEVs) during 1994-1996 [Vyas et al., 1997a]. Since that study, several technological improvements in electric drive technology have occurred, particularly for the HEV. More information is now available on some proposed and prototype HEVs and their components. Vehicle manufacturers like Toyota and Honda have presented their HEVs at U.S. auto shows, while Audi has presented an HEV in Europe. These manufacturers have also released some technical information relating to their HEVs. A joint project aimed at tripling the fuel economy of the light duty vehicles by the U.S. government and U.S. vehicle manufacturers - Partnership for a New Generation of Vehicles (PNGV) - has identified the hybrid electric technology as the leading technology for its future vehicles.

The HEVs are usually equipped with an energy storage device that supplements a power unit by supplying the vehicle with power during acceleration and while it is stopped in traffic. The power unit replenishes this energy storage device during the periods of low demand. Batteries (of several types), arranged in packs, are the leading candidates for the energy storage device. An HEV's battery pack could have sufficient capacity to power the vehicle independent of its power unit. Such battery packs would be charged through grid electricity and by the HEV's power unit when depleted on the road. The distance traveled on battery power alone is often referred to as all-electric or battery-only range. The Two-Stage Delphi Study respondents predicted far greater all-electric range than what is achieved (theoretically) by the Toyota Prius and Audi Duo, two near-term HEVs. The Toyota Prius is not, in fact, designed to use electric power from the grid. The 199496 Delphi Study analysts were concerned that the layout of the study questionnaire may have caused the respondents to characterize long all-electric range HEVs.

The 1994-96 two-stage Delphi Study sought information on battery characteristics for 10 battery technologies, but it did not request separate characterization of batteries for HEVs. Most respondents who provided battery characteristics seemed to have done it for an electric- 
drive vehicle with significant all-electric range. A search of the responses revealed no clear subset of respondents characterizing a grid-independent HEV, such as the Prius. Further, no respondent projected a specific power value for the nickel metal hydride battery as high as what is reported for the Prius battery. Now we know that some battery types can be optimized for either high specific energy or high specific power. Manufacturers of near-term HEVs are choosing batteries with high specific power and lower energy storage capacity than predicted in the earlier survey. These developments indicate that HEV batteries will be quite different from EV batteries with regard to specific power (higher) and specific energy (lower).

To update the HEV information to the current level, a short questionnaire was prepared that addressed the items that may have restricted HEV responses in the earlier study. As in the case of the 1994-96 Delphi Study, SAE's Cooperative Research Program (SAECRP) helped conduct the survey. SAE-CRP handled the mailing and coordination of the responses. The questionnaire was mailed out to all the respondents of the first- (1994) and second-stage (1996) Delphi questionnaire. This paper summarizes the results of a short survey conducted in the spring of 1998.

About 180 questionnaires were mailed to the participants of the previous surveys; 41 responses were received. Most of the answers were carefully thought out, with supplementary descriptive text. Nevertheless, less than half of the respondents answered the battery question.

\section{HYBRID ELECTRIC VEHICLE CHARACTERISTICS}

A question relating to the attributes of the anticipated top-selling HEV in 2005, 2010, and 2020 asked the respondents to select power plant type; power plant fuel; HEV drive; battery-only range; and differences in cost, emissions, and fuel economy relative to $\mathrm{CV}$. The responses to this question are summarized in Tables 1 , 2 , and 3 .

Table 1 Summary of Responses on Attributes of Anticipated Top-Selling HEV

\begin{tabular}{|c|c|c|c|c|c|c|}
\hline & \multicolumn{6}{|c|}{ Power plant } \\
\hline \multirow{2}{*}{ Type } & \multicolumn{2}{|c|}{2005} & \multicolumn{2}{|c|}{2010} & \multicolumn{2}{|c|}{2020} \\
\hline & Obs & $\%$ & Obs & $\%$ & Obs & $\%$ \\
\hline Spark Ignition & 29 & 76.3 & 17 & 44.7 & 6 & 16.7 \\
\hline $\begin{array}{l}\text { Compression } \\
\text { Ignition }\end{array}$ & 8 & 21.1 & 12 & 31.6 & 2 & 5.5 \\
\hline Fuel Cell & 1 & 2.6 & 6 & 15.8 & 27 & 75.0 \\
\hline Others & 0 & & 3 & 7.9 & 1 & 2.8 \\
\hline \multirow[t]{2}{*}{ Total } & 38 & 100 & 38 & 100 & 36 & 100 \\
\hline & \multicolumn{6}{|c|}{ Power plant Fuel } \\
\hline \multirow{2}{*}{ Type } & \multicolumn{2}{|c|}{2005} & \multicolumn{2}{|c|}{2010} & \multicolumn{2}{|c|}{2020} \\
\hline & Obs & $\%$ & Obs & $\%$ & Obs & $\%$ \\
\hline Gasoline & 30 & 76.9 & 18 & 46.1 & 12 & 32.4 \\
\hline Diesel & 5 & 12.8 & 11 & 28.2 & 2 & 5.4 \\
\hline Hydrogen & $\overline{0}$ & & $\overline{0}$ & & 11 & 29.8 \\
\hline Methanol & 0 & & 4 & 10.3 & 6 & 16.2 \\
\hline Others & $\overline{4}$ & 10.3 & 6 & 15.4 & 6 & 16.2 \\
\hline \multirow[t]{2}{*}{ Total } & 39 & 100 & 39 & 100 & 37 & 100 \\
\hline & \multicolumn{6}{|c|}{ HEV Drive } \\
\hline \multirow{2}{*}{ Type } & \multicolumn{2}{|c|}{2005} & \multicolumn{2}{|c|}{2010} & \multicolumn{2}{|c|}{2020} \\
\hline & Obs & $\%$ & Obs & $\%$ & Obs & $\%$ \\
\hline Parallel & 17 & 48.6 & 11 & 32.3 & 8 & 24.2 \\
\hline Series & 11 & 31.4 & 16 & 47.1 & 18 & 54.6 \\
\hline Series/Parallel & 7 & 20.0 & 7 & 20.6 & 7 & $\overline{21.2}$ \\
\hline Total & 35 & 100 & 34 & 100 & 33 & 100 \\
\hline
\end{tabular}




\section{DISCLAIMER}

This report was prepared as an account of work sponsored by an agency of the United States Government. Neither the United States Government nor any agency thereof, nor any of their employees, make any warranty, express or implied, or assumes any legal liability or responsibility for the accuracy, completeness, or usefuiness of any information, apparatus, product, or process disclosed, or represents that its use would not infringe privately owned rights. Reference herein to any specific commercial product, process, or service by trade name, trademark, manufacturer, or otherwise does not necessarily constitute or imply its endorsement, recommendation, or favoring by the United States Government or any agency thereof. The views and opinions of authors expressed herein do not necessarily state or reflect those of the United States Government or any agency thereof. 


\section{DISCLAIMER}

Portions of this document may be illegible in electronic image products. Images are produced from the best available original document. 
Table 2 Top-Selling HEV Battery-Only Range and Cost

\begin{tabular}{|c|l|l|r|r|r|c|}
\hline Attribute & Year & Obs & Mean & Mode & Median & Quartiles 1/3 \\
\hline \multirow{3}{*}{ Battery Range (km) } & 2005 & 36 & 49 & 50 & 30 & $18 / 53$ \\
\cline { 2 - 7 } & 2010 & 36 & 70 & 30 & 50 & $20 / 100$ \\
\cline { 2 - 7 } & 2020 & 35 & 92 & 50 & 50 & $25 / 100$ \\
\hline \multirow{3}{*}{$\begin{array}{l}\text { Cost Difference (\$) } \\
\text { Maintenance Cost }\end{array}$} & 2005 & 40 & 13,100 & 10,000 & 10,000 & $5000 / 20000$ \\
\cline { 2 - 7 } $\begin{array}{l}\text { Difference } \\
\text { (cents/mile) }\end{array}$ & 2010 & 40 & 9,763 & 5,000 & 5,500 & $4500 / 15750$ \\
\cline { 2 - 7 } & 2020 & 39 & 6,667 & 0 & 3,000 & $0 / 12000$ \\
\cline { 2 - 7 } & 2010 & 29 & 6.8 & 0.0 & 1.0 & $0.0 / 4.0$ \\
\cline { 2 - 7 } & 2020 & 28 & 7.7 & 0.0 & 0.0 & $0.0 / 2.0$ \\
\hline
\end{tabular}

Table 3 Top-Selling HEV Emissions and Fuel Economy Ratio to Gasoline Vehicle

\begin{tabular}{|l|l|c|c|c|c|c|}
\hline Attribute & Year & Obs & Mean & Mode & Median & Quartiles 1/3 \\
\hline \multirow{3}{*}{$\mathrm{NO}_{x}$} & 2005 & 31 & 0.63 & 0.50 & 0.50 & $0.40 / 1.00$ \\
\cline { 2 - 7 } & 2010 & 32 & 0.47 & 1.00 & 0.37 & $0.10 / 0.85$ \\
\cline { 2 - 7 } & 2020 & 31 & 0.23 & 0.00 & 0.10 & $0.01 / 0.28$ \\
\hline \multirow{3}{*}{ Particulate } & 2005 & 24 & 0.84 & 1.00 & 0.90 & $0.50 / 1.00$ \\
\cline { 2 - 7 } & 2010 & 26 & 0.65 & 1.00 & 0.78 & $0.23 / 1.00$ \\
\cline { 2 - 7 } & 2020 & 25 & 0.25 & 1.00 & 0.01 & $0.00 / 1.00$ \\
\hline \multirow{3}{*}{ Fuel Economy } & 2005 & 34 & 1.70 & 2.00 & 1.90 & $1.25 / 2.00$ \\
\cline { 2 - 7 } & 2010 & 35 & 2.08 & 2.00 & 2.00 & $1.50 / 2.50$ \\
\cline { 2 - 7 } & 2020 & 34 & 2.59 & 3.00 & 2.50 & $1.76 / 3.00$ \\
\hline
\end{tabular}

A majority of the experts predicted that HEVs would have a spark-ignition gasoline engine in 2005 and fuel cell power plant by 2020 . A majority of the respondents did not predict that the compression-ignition diesel: engine would be the top power-plant choice during the three forecast years. The mean share for compressionignition diesel engines did rise between 2005 and 2010, but it then fell sharply in 2020. The 2020 fuel shares were projected about equal for gasoline and hydrogen, with methanol a distant third. While $75 \%$ of the respondents predicted that the fuel cell would be the fuel of choice, $30 \%$ predicted hydrogen as the most likely fuel in 2020. The respondents seem to have viewed hydrogen's infrastructure costs as very high. In their opinion, fuels that use the existing infrastructure would most likely be used in the future fuel-cell HEVs. These hydrogen fuel share predictions are lower than those in the 1994-96 two-stage Delphi Study, in which 27 out of 58 respondents predicted that hydrogen would be the fuel cell fuel in 2020 . The early HEVs were predicted to have parallel or series/parallel drive, while the future HEVs were projected to have series drive. In fact, because the fuel cell vehicle has to be a series drive vehicle, the predicted share of series drive vehicles should have risen as fuel cell share rose. The survey responses validate this scenario. Also, the share of series drive vehicles is more likely to rise as the allelectric range increases because the sizes of electric components would be more suitable. The top-selling HEVs are projected to have enough battery-alone range to make use of electric power from the grid. They cost significantly more than the conventional vehicles (CVs), with the predicted cost differential dropping over time.

The projected mean battery-only range is $49 \mathrm{~km}$ in 2005, $70 \mathrm{~km}$ in 2010, and $92 \mathrm{~km}$ in 2020. These projections, as well as the mode and median, seem reasonable but strikingly different in comparison with those from the 1994-96 Delphi Study in which a 244-km battery-only range was projected for 2020 . The respondents projected a $66 \%$ higher cost in 2005 and $33 \%$ higher cost in 2020 for the anticipated top-selling HEV vs. a $\$ 20,000 \mathrm{CV}$. The cost projections appear reasonable for HEVs that have a battery-only range of $49 \mathrm{~km}$ [Plotkin et al., 1999]. The respondents projected higher maintenance costs for the HEVs. The maintenance costs are projected to be high, similar to those projected by the 1994-96 Two-Stage Delphi Study, in which HEVs with an internal combustion engine were projected to have 1.5 times the maintenance cost of the $1993 \mathrm{CV}$. The fuel cell HEVs were projected to have maintenance costs twice those of the $1993 \mathrm{CV}$ in that study.

The HEVs are projected to emit less nitrogen oxides and particulate matter than gasoline vehicles. The 2020 fuel cell HEVs are projected to have a fuel economy 2.59 times that of the contemporary gasoline vehicles. This projection is higher than that from the 1994-96 two-stage Delphi Study, in which the 2020 fuel cell HEV was projected to have a fuel economy 1.59 times higher than the gasoline vehicles. The fuel economy projections are closer to the current estimates [Stodolsky et al., 1999]. 
COMPONENT COST - The respondents were asked to rank battery, controller, and motor in the order of their contribution to the cost differential they specified earlier (in Table 4). They ranked the three components 1,2 , and 3 , with 1 being the lowest. The respondents ranked the battery as the main contributor of the cost differential, and the motor and controller nearly tied for the second spot. The stated importance of the motor (a mature technology) to the incremental cost drops slightly into the future. The expected importance of the battery and controller remains about the same. Respondents of the current survey believed that the battery has the greatest potential for cost reduction, while there is little potential for the motor (Table 5).

Table 4 Relative Contribution by Key Components to Incremental HEV Cost

\begin{tabular}{|l|c|c|c|c|c|}
\hline \multirow{2}{*}{$\begin{array}{l}\text { HEV } \\
\text { Component }\end{array}$} & \multicolumn{5}{|c|}{ Importance Ranking } \\
\cline { 2 - 6 } & Year & Obs & Mean & Mode & Median \\
\hline \multirow{3}{*}{ Battery } & 2005 & 35 & 2.31 & 3.00 & 3.00 \\
\cline { 2 - 6 } & 2010 & 35 & 2.40 & 3.00 & 3.00 \\
\cline { 2 - 6 } & 2020 & 34 & 2.41 & 3.00 & 3.00 \\
\hline \multirow{3}{*}{ Controller } & 2005 & 35 & 1.80 & 2.00 & 2.00 \\
\cline { 2 - 6 } & 2010 & 35 & 1.86 & 2.00 & 2.00 \\
\cline { 2 - 6 } & 2020 & 34 & 1.82 & 2.00 & 2.00 \\
\hline \multirow{3}{*}{ Motor } & 2005 & 35 & 1.89 & 1.00 & 2.00 \\
\cline { 2 - 6 } & 2010 & 35 & 1.74 & 1.00 & 2.00 \\
\cline { 2 - 6 } & 2020 & 34 & 1.76 & 1.00 & 2.00 \\
\hline
\end{tabular}

Table 5 Component with the Greatest Potential for Cost Reduction

\begin{tabular}{|l|c|}
\hline Component & Greatest Potential \\
\hline Battery & 24 \\
\hline Controller & 9 \\
\hline Motor & 2 \\
\hline Total & 35 \\
\hline
\end{tabular}

FUTURE HEV DEVELOPMENT - Since the personal vehicle preference in the United States and elsewhere has changed significantly in the past few years, respondents were asked to specify their priority for future developments. They ranked four vehicle classes: passenger car, minivan, sports utility, and pickup truck. Table 6 summarizes the responses where a higher value indicates a higher ranking. Surprisingly, the mean values of responses indicate that the experts treated the four vehicle classes nearly equal. The median and modal values seem to indicate that the first HEVs should be in the passenger car and sports utility classes.

Table 6 HEV Development Priority Ranking ( $1=$ Low)

\begin{tabular}{|l|c|c|c|c|}
\hline \multicolumn{1}{|c|}{ Vehicle Type } & Obs & Mean & Mode & Median \\
\hline Passenger Car & 39 & 2.69 & 4.00 & 3.00 \\
\hline Mini-van & 39 & 2.38 & 2.00 & 2.00 \\
\hline Sports Utility & 39 & 2.54 & 3.00 & 3.00 \\
\hline Pick-up truck & 39 & 2.38 & 1.00 & 2.00 \\
\hline
\end{tabular}

\section{BATTERY CHARACTERISTICS}

A question on battery characteristics sought information on specific power, specific energy, and cycle life when the battery is used in the state-of-charge (SOC) range of $80-60 \%$, as well as cost. At the beginning of the question, respondents were made aware that the battery characteristics in the earlier two-stage Delphi survey provided conflicting results for HEVs. When the average values from the earlier survey were used in an analysis, predictions relating to HEV curb weight, range, and acceleration could not be met within some reasonable margins [Vyas et al. 1997b]. As noted previously, the earlier Delphi survey solicited battery information applicable to both EVs and HEVs with one question. Ten battery types were covered in that survey. Survey analysts felt that the layout of the battery question probably caused the respondents to characterize HEVs with long all-electric (i.e., battery-only) range. Since that survey, batteries with much higher specific power and lower specific energy than predicted previously are being produced and used in the near-term hybrid applications.

Characteristics were sought for the three most promising battery types: (1) lead acid, (2) lithium ion, and (3) nickel metal hydride. The respondents were asked to provide battery characteristics for 2005, 2010, and 2020. Table 7 summarizes the responses, listing such descriptive statistics as number of observations, mean, median, and inter-quartile range.

The battery characteristic responses showed a few surprises. Less than half of the respondents felt knowledgeable enough to respond. The number of observations in the table ranges from 13 to 19 . Thus, only $32-46 \%$ of the 41 respondents answered this question. In comparison, the participation rate for lead acid, lithium polymer, and nickel metal hydride batteries ranged from 38 to $59 \%$ in the two-stage Delphi Study [Vyas et al., 1997a]. A few respondents were very optimistic, assigning extreme values to the battery attributes, particularly to cycle life. Consequently, the descriptive statistics in the table often show that the median and first quartile values are closer to each other than are the mean and median values. The statistics for initial cost of all three batteries and specific energy of lithium ion and nickel metal hydride batteries are exceptions to this. Even though the forwarding letter and the questionnaire mentioned the use of high-specificpower and low-specific-energy batteries by producers of the near-term hybrids, the respondents apparently believed that batteries with moderate to high specific energy were necessary to create HEVs with all-electric travel capability. Compared to the $480-W / \mathrm{kg}$ specific power and $41-\mathrm{Wh} / \mathrm{kg}$ specific energy of the Toyota Prius nickel metal hydride battery, the 2005 nickel metal hydride battery is predicted to have $308 \mathrm{~W} / \mathrm{kg}$ specific power and $81 \mathrm{Wh} / \mathrm{kg}$ specific energy.

The respondents projected steady improvements in all battery attributes. The projected improvement was the highest in cycle life for both lithium ion and nickel metal 
Table 7 Characteristics of Three Promising Batteries for HEVs

\begin{tabular}{|c|c|c|c|c|c|c|c|c|c|c|c|c|c|}
\hline \multirow[b]{2}{*}{ Battery } & \multirow[b]{2}{*}{ Characteristics } & \multicolumn{4}{|c|}{ Year 2005} & \multicolumn{4}{|c|}{ Year 2010} & \multicolumn{4}{|c|}{ Year 2020} \\
\hline & & Obs & Mean & Median & $\begin{array}{c}\text { Quartiles } \\
1 / 3\end{array}$ & Obs & Mean & Median & $\begin{array}{c}\text { Quartiles } \\
1 / 3\end{array}$ & Obs & Mean & Median & $\begin{array}{c}\text { Quartiles } \\
1 / 3\end{array}$ \\
\hline \multirow[t]{4}{*}{ Lead Acld } & $\begin{array}{c}\text { Specific Energy } \\
(\mathrm{Wh} / \mathrm{kg})\end{array}$ & 18 & 51 & 41 & $40 / 50$ & 18 & 55 & 46 & $41 / 50$ & 17 & 58 & 50 & $47 / 55$ \\
\hline & \begin{tabular}{|c|} 
Specific Power \\
(W/kg)
\end{tabular} & 16 & 280 & 155 & $143 / 250$ & 16 & 363 & 183 & $157 / 325$ & 16 & 406 & 210 & $195 / 325$ \\
\hline & $\begin{array}{c}\text { Cycle Life at } \\
80-60 \% \text { SOC }\end{array}$ & 13 & 1,055 & 620 & $500 / 800$ & 13 & 1,374 & 750 & $600 / 1000$ & 13 & 1,683 & 1,000 & $600 / 1200$ \\
\hline & $\begin{array}{c}\text { Initial Cost } \\
(\$ / \mathrm{kWh})\end{array}$ & 17 & 170 & 180 & $150 / 200$ & 18 & 159 & 160 & $120 / 190$ & 17 & 156 & 160 & $120 / 200$ \\
\hline \multirow[t]{4}{*}{ Lithlum lon } & $\begin{array}{c}\text { Specific Energy } \\
(W h / k g)\end{array}$ & 19 & 109 & 100 & $80 / 105$ & 19 & 129 & 120 & $97 / 120$ & 18 & 145 & 130 & $105 / 147$ \\
\hline & \begin{tabular}{|c|} 
Specific Power \\
(W/kg)
\end{tabular} & 17 & 339 & 200 & $175 / 200$ & 17 & 430 & 250 & $210 / 300$ & 17 & 501 & 300 & $230 / 500$ \\
\hline & $\begin{array}{l}\text { Cycle Life at } \\
80-60 \% \text { SOC }\end{array}$ & 13 & 2,362 & 800 & $700 / 1000$ & 13 & 3,454 & 1,200 & $\begin{array}{l}1000 I \\
2000\end{array}$ & 13 & 4,619 & 1,400 & $\begin{array}{l}1200 / \\
2000 \\
\end{array}$ \\
\hline & $\begin{array}{c}\text { Initial Cost } \\
(\$ / k W h)\end{array}$ & 17 & 503 & 400 & $300 / 700$ & 18 & 367 & 300 & $200 / 525$ & 17 & 306 & 200 & $150 / 550$ \\
\hline \multirow[t]{4}{*}{$\begin{array}{c}\text { Nickel Metal } \\
\text { Hydride }\end{array}$} & \begin{tabular}{|c|} 
Specific Energy \\
$(W \mathrm{~h} / \mathrm{kg})$
\end{tabular} & 19 & 81 & 70 & $60 / 77$ & 19 & 95 & 80 & $72 / 97$ & 18 & 107 & 90 & $76 / 115$ \\
\hline & \begin{tabular}{|c|} 
Specific Power \\
$(W / \mathrm{kg})$
\end{tabular} & 17 & 308 & 200 & $165 / 400$ & 17 & 381 & 250 & $190 / 500$ & 17 & 445 & 300 & $210 / 600$ \\
\hline & $\begin{array}{c}\text { Cycle Life at } \\
80-60 \% \text { SOC }\end{array}$ & 13 & 2,877 & 1,000 & $800 / 1200$ & 13 & 4,238 & 1,500 & $\begin{array}{l}1000 / \\
2000\end{array}$ & 13 & 4,927 & 2,000 & $\begin{array}{c}1300 / \\
3000 \\
\end{array}$ \\
\hline & $\begin{array}{c}\text { Initial Cost } \\
(\$ / k W h)\end{array}$ & 17 & 451 & 450 & $300 / 600$ & 18 & 375 & 375 & $281 / 450$ & 17 & 336 & 350 & $250 / 400$ \\
\hline
\end{tabular}

hydride batteries. The respondents projected a substantial reduction in the initial cost during the first five years, particularly for the lithium ion and nickel metal hydride batteries. Compared with the results from the. Two-Stage Delphi Study, the values in the table show much higher specific power and cycle life, moderately higher to slightly lower specific energy, and lower initial cost. The respondents seem to have evaluated the new developments in the battery technology for the HEVs while providing their estimates.

Following the battery characteristic question, the respondents were asked to give their opinions on the effect of their battery characteristics on a few vehicle attributes. They were asked to select the most likely battery type for each of the three years. They were also asked to provide their estimates of HEV curb weight, battery-only range, and acceleration times. Information on time to reach from 0 to $50 \mathrm{kph}$ and from 50 to $100 \mathrm{kph}$ on battery power was requested. Table 8 summarizes the responses to these questions.

A majority of respondents, 12 out of 21 , selected the nickel metal hydride battery as the most likely HEV battery in 2005, while 6 respondents selected lead acid and 3 selected lithium ion. The lithium ion battery was the battery of choice for 2010 and 2020 . Twelve out of 20 respondents selected the lithium ion battery in 2010 , and 14 out of 18 respondents selected the lithium ion battery in 2020 . The nickel metal hydride battery was selected by 5 and 4 respondents for 2010 and 2020, respectively. Only 3 respondents selected the lead acid battery for 2010 .

The respondents projected the HEV curb weight to decline from a mean of $1,397 \mathrm{~kg}$ in 2005 to a mean of $1,231 \mathrm{~kg}$ in 2020 (a 12\% decrease). A majority of this decrease, $8 \%$, would take place during the first five years. They predicted the mean battery-only range at $38 \mathrm{~km}$ in 2005, $62 \mathrm{~km}$ in 2010, and $73 \mathrm{~km}$ in 2020.

The opinions on battery-only range differed widely, with some respondents predicting no ability to travel on battery-only and a few predicting very limited (5-7 km) battery-only capability. Consequently, mean and median values for the battery-only range differed substantially, and a large inter-quartile-range was predicted. This type of variation in opinions on an emerging technology is understandable. The HEV technology has the potential to reduce urban emissions and overall petroleum consumption if it can use grid electricity. However, the batteries that would store the grid electricity for later use are expensive and would reduce the affordability - and market share - of an HEV, thereby reducing the overall emissions and petroleum reduction benefits. The Toyota Prius does not use grid electricity and can travel on battery power only at speeds below $24 \mathrm{kph}$. Thus, it does not have any practical battery-only range. The Prius represents an HEV configuration in which the battery is used to augment the gasoline engine power during acceleration and to reduce engine idling while stopped in traffic. Many respondents seem to have visualized a different HEV configuration. 
Table 8 Most Likely Battery Type and Other Battery-Related Responses

\begin{tabular}{|c|r|r|r|r|r|r|r|r|r|r|r|r|}
\hline & \multicolumn{4}{|c|}{ Year 2005 } & \multicolumn{4}{c|}{ Year 2010 } & \multicolumn{4}{c|}{ Year 2020 } \\
\cline { 2 - 14 } HEV Attribute & Obs & Mean & Median & $\begin{array}{c}\text { Quartiles } \\
1 / 3\end{array}$ & Obs & Mean & Median & $\begin{array}{c}\text { Quartiles } \\
1 / 3\end{array}$ & Obs & Mean & Median & $\begin{array}{c}\text { Quartiles } \\
1 / 3\end{array}$ \\
\hline $\begin{array}{c}\text { Most Likely } \\
\text { Battery Type }\end{array}$ & \multicolumn{3}{|c|}{ Nickel Metal Hydride } & \multicolumn{3}{c|}{ Lithium lon } & \multicolumn{4}{|c|}{ Lithium lon } \\
\hline Curb Wt (kg) & 16 & 1,397 & 1,450 & $1287 / 1512$ & 16 & 1,284 & 1,350 & $1175 / 1412$ & 16 & 1,231 & 1,200 & $1100 / 1312$ \\
\hline $\begin{array}{c}\text { Battery-only } \\
\text { Range (km) }\end{array}$ & 21 & 38 & 25 & $10 / 40$ & 20 & 62 & 50 & $10 / 63$ & 19 & 73 & 50 & $10 / 70$ \\
\hline $\begin{array}{c}0-50 \text { kph Time } \\
\text { (s) }\end{array}$ & 20 & 5.4 & 5.0 & $4 / 6$ & 19 & 4.8 & 5.0 & $4 / 5$ & 19 & 4.6 & 4.5 & $4 / 5$ \\
\hline $\begin{array}{c}50-100 \mathrm{kph} \mathrm{Time} \\
(\mathrm{s})\end{array}$ & 20 & 9.2 & 8.5 & $7.5 / 11$ & 19 & 8.4 & 8.0 & $6 / 10$ & 19 & 8.0 & 8.0 & $6 / 9.5$ \\
\hline
\end{tabular}

The respondents to the battery question predicted a lower battery-only range than did the whole group's prediction for the battery range of the top-selling HEV described earlier (Table 2). A substantial majority, 36 out of 41 , responded to the first question about the topselling HEV. Compared to the projected mean batteryonly range of 49,70 , and $92 \mathrm{~km}$ for the top-selling HEV for the three years of interest, respondents to the battery characteristic question projected a lower mean range of 38,62 , and $73 \mathrm{~km}$ for the three years of interest. The respondents to the battery characteristic question seem to recognize the cost impacts of a high battery-only range during the introduction years. They, however, agree with the whole group (responding to the top-selling HEV question) regarding the need for increased batteryonly range for emissions and petroleum reduction benefits. Consequently, they project continuous: increases in the battery-only range with more improvement during the first five years. The 1995 Nationwide Personal Transportation Survey [FHWA, 1997] shows that a typical household vehicle travels $64 \mathrm{~km} /$ day. Thus, the respondents' projections would allow all-electric operation to displace a large majority of miles from fossil fuel to electricity. Compared to the TwoStage Delphi Survey's mean battery-only range of $270 \mathrm{~km}$ in 2010 and $358 \mathrm{~km}$ in 2020 , these projections appear achievable, yet they would still allow all-electric operation the majority of the time within urban areas.

The mean time for acceleration from 0 to $50 \mathrm{kph}$ is projected as $5.4 \mathrm{~s}$ in $2005,4.8 \mathrm{~s}$ in 2010 , and $4.6 \mathrm{~s}$ in 2020. The mean acceleration time from 50 to $100 \mathrm{kph}$ is $9.2 \mathrm{~s}$ for $2005,8.4 \mathrm{~s}$ for 2010 , and $8 \mathrm{~s}$ for 2020 . The combined mean values for 0 to $100 \mathrm{kph}$ are $14.6 \mathrm{~s}$ in $2005,13.2 \mathrm{~s}$ in 2010 , and $12.6 \mathrm{~s}$ in 2020 . According to the Car \& Driver magazine, a majority of the current conventional vehicles accelerate from 0 to $48 \mathrm{kph}$ (30 mph) in 2.8-3.2 s and from 0 to $96 \mathrm{kph}(60 \mathrm{mph})$ in $8.5-11 \mathrm{~s}$. Tests by Consumer Reports magazine show slightly higher times. On the basis of the projected higher mean acceleration times, survey respondents apparently assumed that the use of battery power (without any assist from the power unit) during local driving would be associated with a driver's willingness to not drive aggressively. Note that the predicted acceleration capabilities are sufficient for even moderately aggressive driving.

\section{BATTERY PACK ATTRIBUTES AND LIFETIME COSTS}

The projected battery-only range and acceleration time can be used to compute the size and attributes of battery packs for each battery type in the three years of interest. Also, a procedure developed at Argonne National Laboratory can be applied to compute average battery cost per kilometer over the lifetime usage of the HEV. The battery packs characterized based on the mean battery-only range may not meet the acceleration time requirements for some battery types, while those characterized based on the mean acceleration times may not meet the range requirements. This range and acceleration capability trade-off, together with average lifetime costs, would provide a good comparison of the battery technologies.

BATTERY PACKS BASED ON BATTERY-ONLY RANGE - Battery packs were characterized to meet the mean battery-only range for each year. For determining the energy contents of each battery pack, a set of base average energy consumption per kilometer and base battery pack mass was used. A U.S. Department of Energy study [Singh et al., 1998] of EVs was used as a guideline. The base energy consumption from the battery was assumed as $230 \mathrm{Wh} / \mathrm{km}$ in 2005 , $224 \mathrm{Wh} / \mathrm{km}$ in 2010 , and $205 \mathrm{Wh} / \mathrm{km}$ in 2020 . The associated base battery pack masses were 145, 125, and $110 \mathrm{~kg}$, respectively. The energy consumption per kilometer was corrected at a rate of $0.66 \%$ per $10 \%$ change in the base battery mass. An iterative procedure was used to arrive at the battery pack characteristics listed in Table 9.

The estimated 0 to $100 \mathrm{kph}$ times in the table are based on the following relationship between acceleration power $P_{\mathrm{a}}$, time $t$ (while accelerating) and vehicle attributes. 
TABLE 9 Battery Pack Attributes when Sized to Meet the Mean Range Requirements

\begin{tabular}{|c|c|c|c|c|c|c|c|}
\hline Battery Type & Year & $\begin{array}{c}\text { Mean } \\
\text { Range } \\
(\mathrm{km})\end{array}$ & $\begin{array}{c}\text { Battery } \\
\text { Pack } \\
\text { Energya } \\
\text { (kWh) }\end{array}$ & $\begin{array}{c}\text { Battery } \\
\text { Pack } \\
\text { Mass } \\
\text { (kg) }\end{array}$ & $\begin{array}{c}\text { Battery } \\
\text { Power } \\
\text { (kW) }\end{array}$ & $\begin{array}{c}\text { Initial } \\
\text { Battery } \\
\text { Cost (\$) }\end{array}$ & $\begin{array}{c}\text { Estimated } 0 \\
\text { to } 100 \mathrm{kph} \\
\text { Time (s) }\end{array}$ \\
\hline \multirow{3}{*}{ Lead Acid } & 2005 & 38 & 8.8 & 174 & 49 & 1,497 & 19.4 \\
\hline & 2010 & 62 & 14.9 & 272 & 99 & 2,371 & 8.4 \\
\hline & 2020 & 73 & 16.4 & 281 & 114 & 2,558 & 6.7 \\
\hline \multirow{3}{*}{ Lithium Ion } & 2005 & 38 & 8.4 & 78 & 26 & 4,239 & 50.4 \\
\hline & 2010 & 62 & 13.7 & 107 & 46 & 5,046 & 17.0 \\
\hline & 2020 & 73 & 14.9 & 103 & 52 & 4,581 & 14.1 \\
\hline \multirow{3}{*}{ Nickel Metal Hydride } & 2005 & 38 & 8.5 & 106 & 33 & 3,851 & 34.0 \\
\hline & 2010 & 62 & 14.0 & 148 & 57 & 5,264 & 13.9 \\
\hline & 2020 & 73 & 15.3 & 143 & 64 & 5,138 & 11.2 \\
\hline
\end{tabular}

a Base energy consumption rates of $230 \mathrm{Wh} / \mathrm{km}$ in 2005, $224 \mathrm{Wh} / \mathrm{km}$ in 2010, and $205 \mathrm{Wh} / \mathrm{km}$ in 2020 are used. The associated base battery masses are 145, 125, and $110 \mathrm{~kg}$, respectively. A $0.66 \%$ change in energy consumption rate per $10 \%$ change in battery mass is applied.

$$
P_{a}=M v \frac{d v}{d t}+\frac{1}{2} \rho A C d v^{3}+M g v C_{r}
$$

Where $M=$ Vehicle mass,

$v=$ Vehicle speed,

$\rho=$ Air density,

$A=$ Vehicle frontal area,

$C_{d}=$ Coefficient of aerodynamic drag,

$g=$ Gravity, and

$C_{r}=$ Coefficient of rolling resistance.

For a vehicle that accelerates from a stop to the maximum speed of $v_{m}$, the power requirements can be restated by integrating the above equation.

$P_{a}=\frac{M}{t_{m}}\left\{\frac{1}{2} v_{m}^{2}+C_{r} g \int_{b}^{(m} v d t\right\}+\frac{\rho A C_{d}}{2 t_{m}} \int_{b}^{m} v^{3} d t$

Where $t_{m}$ is the time taken to reach the maximum speed.

Speed $v$ is a function of time $t$. Under conditions involving smooth acceleration, the speed and time relationship can be approximated as $v=v_{m}\left(t / t_{m}\right)^{x}$. An analysis of published acceleration times indicated that the value of the exponent $x$ ranges from 0.47 to 0.53 . The lower value is applicable to slow accelerating vehicles (approximately a 12-s 0-100 kph time) and the higher value is applicable to fast accelerating vehicles (approximately an 8-s 0-100 kph time).

The acceleration power in the above equations is at the wheels. The battery power should account for motor and transmission efficiencies and other mechanical losses. The assumed motor efficiencies are $90 \%$ in 2005 and $92 \%$ in 2010 and 2020 . The assumed transmission efficiencies are $90 \%$ in $2005,92 \%$ in 2010 , and $94 \%$ in 2020. A factor of 1.05 is applied to allow for other mechanical losses. The mean curb weight projections are used as vehicle mass and are adjusted for changes in battery mass from the base values. The assumed vehicle frontal areas are $2.09 \mathrm{~m}^{2}$ in $2005,2.06$ in 2010 , and 2.01 in 2020 . The coefficient of aerodynamic drag is 0.28 in 2005, 0.27 in 2010 , and 0.25 in 2020. The coefficient of rolling resistance is 0.008 in 2005, 0.0078 in 2010 , and 0.007 in 2020.

Among the three battery types listed in Table 9, the lead acid battery packs have the highest mass and power when sized to provide the same range. Because of their higher power content, lead acid battery packs also have the shortest $0-100-\mathrm{kph}$ times. Comparatively, the lithium ion and nickel metal hydride battery packs do not have adequate power when sized to meet the $38-\mathrm{km}$ range in 2005. The lead acid battery packs have the lowest initial costs. The lithium ion and nickel metal hydride batteries have much higher initial costs compared with lead acid, but they are closer to each other. The trade-off of range and acceleration capability for the 9 battery packs in Table 9 is shown graphically in Figure 1.

Four curves, three for each battery type and a fourth showing the mean response values of battery-only range and 0-100-kph time, are shown in Figure 1. The points falling on or below the "mean of responses" curve are desired, while those falling above the curve fail to meet the mean acceleration requirements. Because the battery packs are sized to meet the mean range requirements, their horizontal axis values are the same. All battery types fall short of the mean acceleration time requirement in 2005, with the lead acid battery pack having the quickest time. By 2010 , the lead acid battery pack exceeds the mean acceleration time requirements, while the time for the nickel metal hydride is $0.6 \mathrm{~s}$ short, and the time for the lithium ion is more than $4 \mathrm{~s}$ short. Both lead acid and nickel metal hydride exceed the mean acceleration time requirement for 2020 , while the 


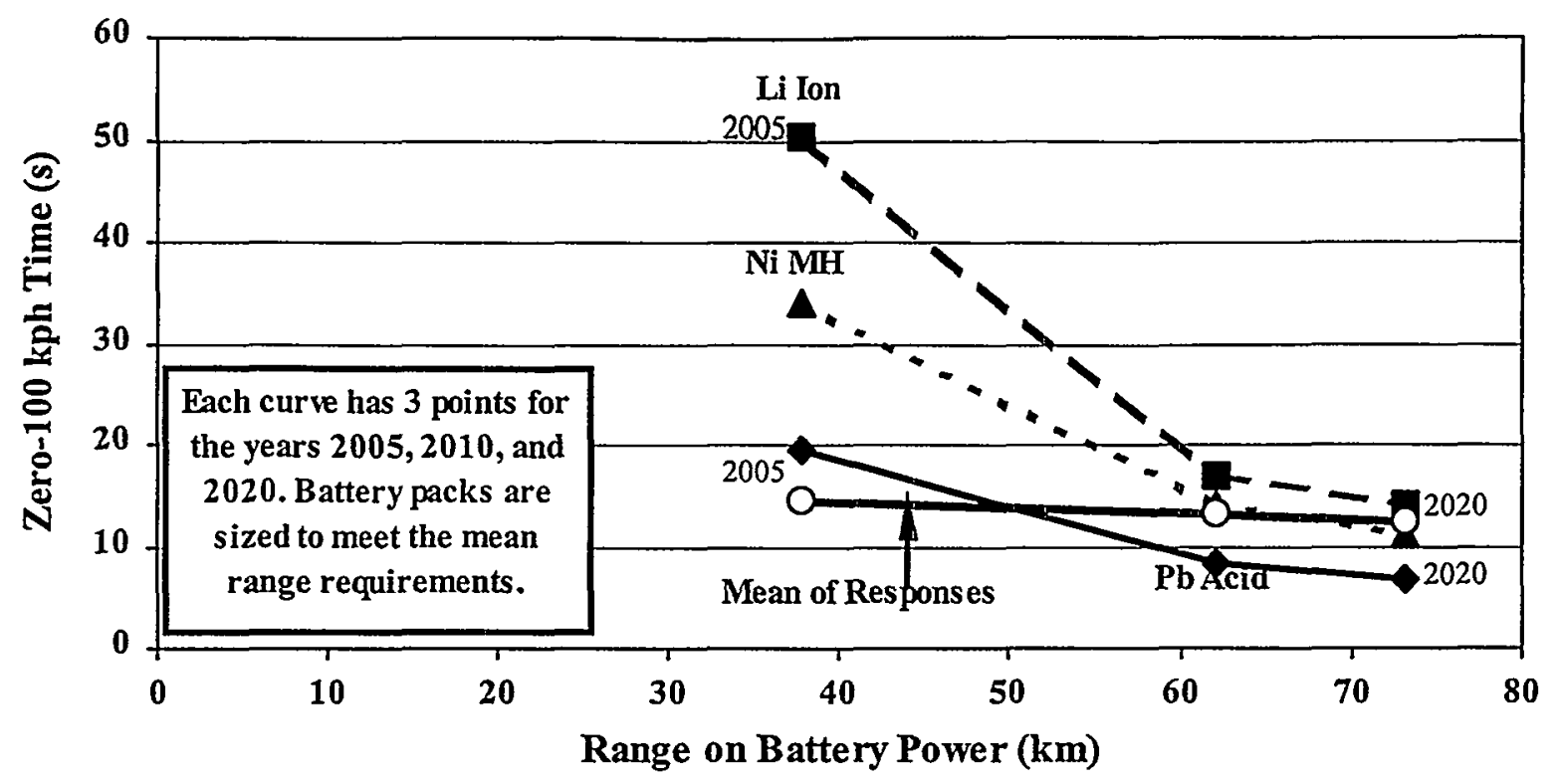

Figure 1 0-100-kph Time and Battery-Only Range - Battery Packs Characterized to Meet the Mean Range Requirements

time for the lithium ion is slightly short. The lithium ion and nickel metal hydride batteries would provide the required battery-only range and with lower mass compared to the lead acid battery, thereby contributing to better energy efficiency.

The lifetime battery costs were computed by using a sequential procedure. The procedure is an improved version of the one used in the two-stage Delphi Study. [Vyas et al., 1997a]. An HEV was assumed to be used $48 \mathrm{~km} /$ day, 365 days/yr, on average. The annual travel would be $17,520 \mathrm{~km}$ at this usage rate. The vehicle would last $12 \mathrm{yr}$ with $210,000-\mathrm{km}$ lifetime travel. The battery pack cycle life was converted to number of years. The cycle life issue is extremely complex. The battery cycle life would differ, depending upon how the battery is charged and discharged. For simplicity, in these illustrative calculations, use of one cycle per day is assumed in every case. The initial and subsequent battery packs were replaced at the end of their respective lives. The costs were discounted at $4 \%$ constant rate for conversion to average annual cost and then allocated over annual distance traveled. The resulting lifetime battery costs for the three battery types are shown in Figure 2.

The lifetime battery costs are the highest for the lead acid battery in 2010 and 2020 , even though its initial costs are lower. Its life cycle is shorter and thus requires more replacement battery packs. The lithium ion battery has the-highest lifetime cost in 2005, but it has the lowest cost by 2020 because of projected improvements. The nickel metal hydride battery has lowest costs in 2005 and 2010.
BATTERY PACKS BASED ON 0-100-kph TIME Battery packs were characterized to match the mean 0-100-kph times. The battery pack power requirements were computed by using the above described equations; corresponding energy content, mass, and initial cost were then computed. The resulting battery-only range was estimated for each battery pack by employing the procedure described earlier. The battery pack attributes are summarized in Table 10.

The lead acid battery packs have the highest mass compared with the corresponding lithium ion or nickel metal hydride battery packs. However, the difference is smaller compared with the battery packs in Table 9 . The lead acid has the lowest initial cost $-20-25 \%$ the cost of the lithium ion and nickel metal hydride battery packs. The lead acid battery packs have the shortest range, plus they fail to meet the mean range requirements of 62 and $73 \mathrm{~km}$ in 2010 and 2020.

The procedure for computing lifetime battery cost was also applied to the battery packs in Table 10. The resulting lifetime costs are shown graphically in Figure 3. The lead acid battery has the lowest cost and a modest battery-only range of $38-46 \mathrm{~km}$. The lithium ion and nickel metal hydride battery packs are projected to provide battery-only ranges that exceed the mean requirements. However, they have higher lifetime battery costs. The lifetime costs of both lithium ion and nickel metal hydride batteries are projected to substantially drop between 2005 and 2010, and the cost of lithium ion is expectsed to surpass that of nickel metal hydride by 2010. The cost reduction potential between 2010 and 2020 is predicted to be lower for the nickel metal hydride. The lithium ion is projected to improve during 


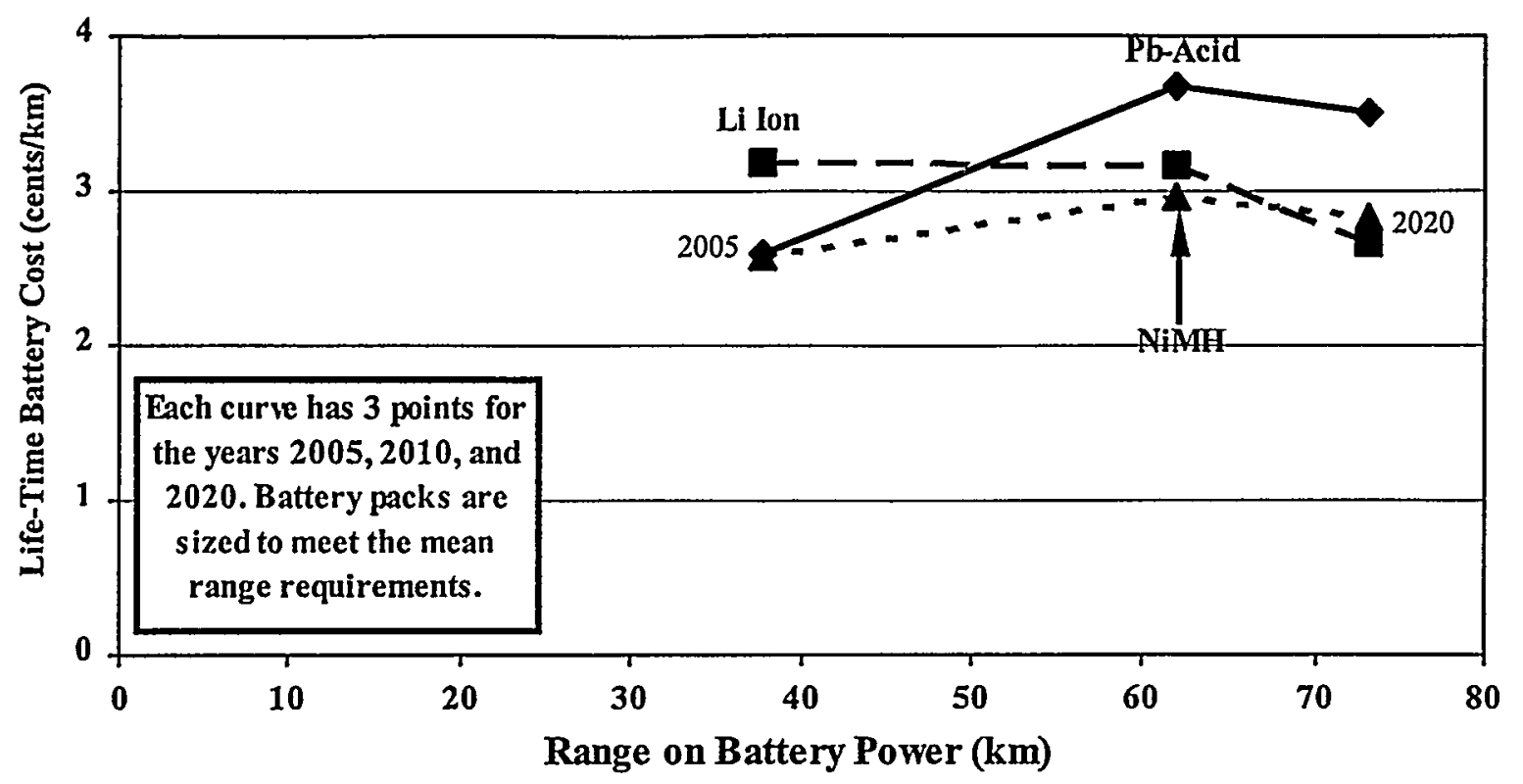

Figure 2 Lifetime Battery Cost and Battery-Only Range - Battery Packs Characterized to Meet the Mean Range Requirements

Table 10 Battery Pack Attributes When Sized to Meet the Mean 0-100-kph Time Requirements

\begin{tabular}{|c|c|c|c|c|c|c|c|}
\hline & Year & $\begin{array}{c}\text { Mean 0-100 } \\
\text { kph Time } \\
\text { (s) }\end{array}$ & $\begin{array}{c}\text { Battery } \\
\text { Pack } \\
\text { Energy } \\
\text { (kWh) }\end{array}$ & $\begin{array}{c}\text { Battery } \\
\text { Pack } \\
\text { Mass } \\
\mathbf{( k g )}\end{array}$ & $\begin{array}{c}\text { Battery } \\
\text { Power } \\
\mathbf{( k W )}\end{array}$ & $\begin{array}{c}\text { Initial } \\
\text { Battery } \\
\text { Cost } \mathbf{( \$ )}\end{array}$ & $\begin{array}{c}\text { Estimated } \\
\text { Range } \\
\mathbf{( k m )}\end{array}$ \\
\hline \multirow{2}{*}{ Lead Acid } & 2005 & 14.6 & 11.0 & 217 & 61 & 1,872 & 46 \\
& 2010 & 13.3 & 8.7 & 159 & 58 & 1,384 & 38 \\
& 2020 & 12.6 & 8.3 & 142 & 58 & 1,290 & 40 \\
\hline \multirow{2}{*}{ Lithium lon } & 2005 & 14.6 & 19.5 & 180 & 61 & 9,813 & 83 \\
& 2010 & 13.3 & 17.3 & 134 & 58 & 6,343 & 77 \\
& 2020 & 12.6 & 16.7 & 115 & 58 & 5,114 & 81 \\
\hline \multirow{2}{*}{ Nickel Metal Hydride } & 2005 & 14.6 & 15.9 & 197 & 61 & 7,161 & 67 \\
& 2010 & 13.3 & 14.3 & 151 & 58 & 5,377 & 63 \\
& 2020 & 12.6 & 13.8 & 129 & 58 & 4,643 & 67 \\
\hline
\end{tabular}

that time, with its lifetime cost approaching that of lead acid.

The battery data analysis showed that HEVs with substantial battery-only range would require large battery packs, with $115-280 \mathrm{~kg}$ mass. Also, the recent developments in the battery field have shown that some battery technologies are amenable to designs that provide a varying balance between specific power and specific energy. Consequently, the range and acceleration time trade-off could lead to a variety of HEV and battery pack configurations that appeal to different consumer segments. The on-board power unit would supplement battery power; consequently the HEVs, could have much quicker acceleration times on combined battery and power-unit power that would be similar to the acceleration times of today's sports cars.
The HEV lifetime battery cost analysis based on the mean acceleration provided a range of cost at 1.8$5.6 \mathrm{cents} / \mathrm{km}$. This cost is over and above the energy cost. If the battery packs were charged at a special rate during nighttime, the electricity cost would be much lower. Also, because an HEV eliminates its power unit's idling, its fuel economy on fossil (or renewable) fuel would be higher than that of a $\mathrm{CV}$, even when its acceleration time is very low.

\section{PERSONAL VISION OF THE MOST DESIRABLE HEV}

A question asked the respondents to describe their personal vision of the most desirable HEV and its likely characteristics when introduced in the U.S. market in the next decade. The responses to this question are summarized in Tables 11-13. The tables also present a 


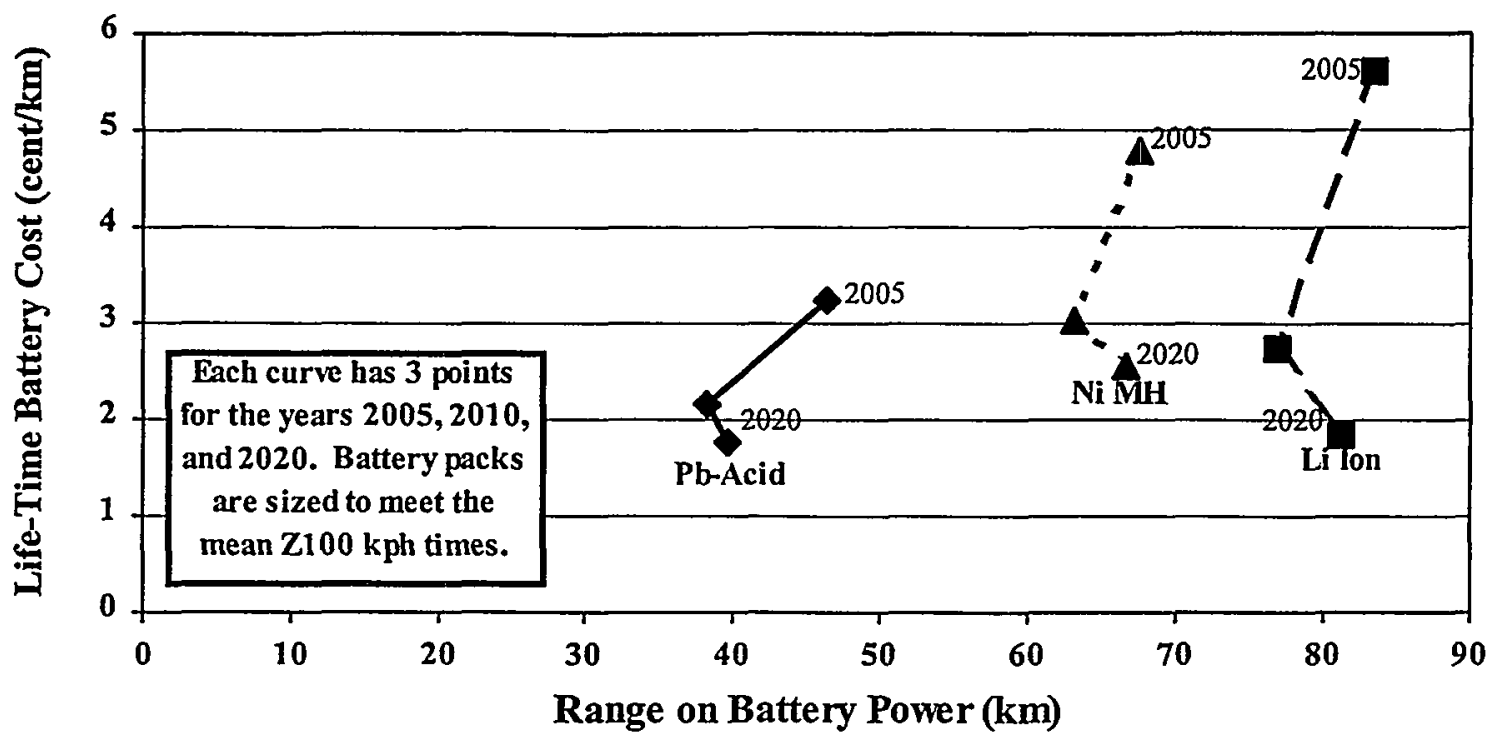

Figure 3 Lifetime Battery Cost and Battery-Only Range - Battery Packs Characterized to Meet the Mean 0-100-kph Time Requirements

Table 11 Year 2005 "Top-Selling" vs. "Vision" HEV Power Plant Attributes

\begin{tabular}{|c|c|c|c|c|}
\hline \multicolumn{5}{|c|}{ Power Plant } \\
\hline \multirow[t]{2}{*}{ Type } & \multicolumn{2}{|c|}{ Top-Selling } & \multicolumn{2}{|c|}{ Vision } \\
\hline & Obs & $\%$ & Obs & $\%$ \\
\hline Spark Ignition & 29 & 76.3 & 22 & 57.9 \\
\hline Compression Ignition & 8 & 21.1 & 10 & 26.3 \\
\hline Fuel Cell & 1 & 2.6 & 5 & 13.2 \\
\hline Others & 0 & & 1 & 2.6 \\
\hline Total & 38 & 100 & 38 & 100 \\
\hline \multicolumn{5}{|c|}{ Power Plant Fuel } \\
\hline Type & \multicolumn{2}{|c|}{ Top-Selling } & \multicolumn{2}{|c|}{ Vision } \\
\hline & Obs & $\%$ & Obs & $\%$ \\
\hline Gasoline & 30 & 76.9 & 25 & 67.6 \\
\hline Diesel & 5 & 12.8 & 7 & 18.9 \\
\hline Hydrogen & 0 & & 0 & \\
\hline Methanol & 0 & & 0 & \\
\hline Others & 4 & 10.3 & 5 & 13.5 \\
\hline Total & 39 & 100 & 37 & 100 \\
\hline \multicolumn{5}{|c|}{ HEV Drive } \\
\hline Type & \multicolumn{2}{|c|}{ Top-Selling } & \multicolumn{2}{|c|}{ Vision } \\
\hline & Obs & $\%$ & Obs & $\%$ \\
\hline Parallel & 17 & 48.6 & 15 & 42.9 \\
\hline Series & 11 & 31.4 & 15 & 42.9 \\
\hline Series/Parallel & 7 & 20.0 & 5 & 14.2 \\
\hline Total & 35 & 100 & 35 & 100 \\
\hline
\end{tabular}


Table 12 Year 2005 "Top-Selling" vs. "Vision" HEV Battery-Only Range and Cost

\begin{tabular}{|c|c|c|r|r|r|c|}
\hline Attribute & 2005 & Obs & Mean & Mode & Median & Quartiles 1/3 \\
\hline \multirow{2}{*}{ Battery Range (km) } & Top-selling & 36 & 49 & 50 & 30 & $18 / 53$ \\
\cline { 2 - 7 } & Vision & 35 & 50 & 50 & 35 & $10.0 / 70.0$ \\
\hline \multirow{2}{*}{ Cost Difference (\$) } & Top-selling & 40 & 13,100 & 10,000 & 10,000 & $5000 / 20000$ \\
\cline { 2 - 7 } & Vision & 39 & 9,600 & 0 & 6,000 & $3000 / 15000$ \\
\hline
\end{tabular}

Table 13 Year 2005 "Top-Selling" vs. "Vision" HEV Other Characteristics (Ratio to Gasoline)

\begin{tabular}{|l|c|c|c|c|c|c|}
\hline \multicolumn{1}{|c|}{ Attribute } & Year & Obs & Mean & Mode & Median & Quartiles 1/3 \\
\hline \multirow{2}{*}{$\mathrm{NO}_{\mathrm{x}}$} & Top-selling & 31 & 0.63 & 0.50 & 0.50 & $0.40 / 1.00$ \\
\cline { 2 - 7 } & Vision & 33 & 0.54 & 1.00 & 0.50 & $0.10 / 1.00$ \\
\hline \multirow{2}{*}{ Particulates } & Top-selling & 26 & 0.84 & 1.00 & 0.15 & $0.23 / 1.00$ \\
\cline { 2 - 7 } & Vision & 30 & 0.61 & 1.00 & 0.50 & $0.07 / 1.00$ \\
\hline \multirow{2}{*}{ Fuel Economy y } & Top-selling & 34 & 1.70 & 2.00 & 1.90 & $1.25 / 2.00$ \\
\cline { 2 - 7 } & Vision & 35 & 1.99 & 2.00 & 2.00 & $1.30 / 2.25$ \\
\hline \multirow{2}{*}{ HEV Cost } & Top-selling & 40 & 1.66 & 1.50 & 1.50 & $1.25 / 2.00$ \\
\cline { 2 - 7 } & Vision & 39 & 1.48 & 1.00 & 1.30 & $1.15 / 1.75$ \\
\hline
\end{tabular}

comparison with the year 2005 top-selling HEV from Tables 1-3. The respondents predicted their "vision" HEV to have a spark-ignition engine with gasoline as the fuel, like the "top-selling" HEV. The means of responses relating to the type of HEV drive and battery-only range are also very similar. However, the responses differ on the cost of the future HEV. The "vision" HEV is projected to cost $48 \%$ more than a $\$ 20,000$ conventional gasoline vehicle, while the "top-selling" HEV was projected earlier to cost $66 \%$ more. It is not surprising that the. respondents projected their "vision" HEVs to produce. less $\mathrm{NO}_{\mathrm{x}}$ and particulates and to have higher fuel economy.

\section{SUMMARY}

Hybrid-electric technology is a leading technology for increasing vehicle fuel economy, reducing greenhouse gas emissions, and reducing criteria pollutant emissions when equipped to have battery-only range. The mean values of responses by industry experts to a 1998 survey appear to provide a realistic and technically consistent view of the future HEVs, in contrast to the earlier two-stage Delphi survey.

The fuel cell is projected to be the most likely powerplant for HEVs in 2020; instead of hydrogen, however, such liquid fuels as gasoline and methanol will likely be used. Projected HEV fuel economy ranges from 1.7 to 2.6 times the conventional vehicle fuel economy. Thus, even with the fuel cell as its power plant, the HEV is not likely to have a fuel economy three times that of conventional vehicle (a PNGV goal). The future HEVs are projected to emit significantly less $\mathrm{NO}_{x}$ and particulate matter than CVs. The mean projections indicate that the cost of an HEV will drop from $66 \%$ to $33 \%$ more than a $\$ 20,000 \mathrm{CV}$ by 2020 . The typical respondent, however, characterized by the median and modal statistics, expected the cost penalty to drop to $15 \%$ (median) or zero (mode) by 2020.

\section{ACKNOWLEDGMENTS}

The authors thank Dr. Philip Patterson of the Office of Transportation Technologies, U.S. Department of Energy, for his support and valuable guidance. Thanks are also due to Gary Pollak of SAE International and to the staff of SAE's Cooperative Research Program Office. The authors also thank the experts who devoted their time in responding to the questionnaire. Thanks to Kevin A. Brown, Argonne National Laboratory, for editing this paper and to Vicki Skonicki, also of Argonne National Laboratory, for providing word processing help. The U.S. Department of Energy, Assistant Secretary for Energy Efficiency and Renewable Energy sponsored this work under contract W-31-109-Eng-38.

\section{REFERENCES}

1. FHWA (1997), 1995 NPTS Data Files: Compact Disk and Codebook, Federal Highway Administration, U.S. Department of Transportation, Washington, D.C.

2. Plotkin, S., et al. (1999), Hybrid Electric Vehicles Total Energy Cycle Analysis, Presented at the $78^{\text {th }}$ Annual Meeting of the Transportation Research Board, Washington, D.C.

3. Singh, M.K., et al. (1998), Total Energy Cycle Assessment of Electric and Conventional Vehicles: An Energy and Environmental Analysis, Vol. I-IV, NTIS Report ANL/ES/RP-96387-Vol. I through Vol. IV, Washington, D.C. 
4. Stodolsky, F., et al. (1999), Total Fuel Cycle Impacts of Advanced Vehicles, Presented at the 1999 SAE International Congress and Exposition at Detroit, Michigan, SAE Paper No. 1999-01-0322, SAE International, Warrendale, PA.

5. Vyas, A.D., H.K. Ng, D.J. Santini, and J.L. Anderson (1997a), Electric and Hybrid Electric Vehicles: $A$ Technology Assessment Based on a Two-Stage Delphi Study, Argonne National Laboratory Report ANL/ESD-36, Argonne, IL.

6. Vyas, A.D., H.K. Ng, D.J. Santini, and J.L. Anderson (1997b), Batteries for Electric Drive Vehicles: Evaluation of Future Characteristics and Costs Through a Delphi Study, in State of the Alternative Fuel Technologies - 1997, SAE International Report SP-1274, pp. 13-34, Warrendale, PA. 